\title{
Spatial-territorial factors of economic growth in the Russian Federation
}

\author{
R.R. Akhunov, A.V. Yangirov $\bowtie$ \\ Ufa Federal Research Centre, Russian Academy of Sciences, Ufa, Russia; \\ jangirovav@list.ru
}

\begin{abstract}
Relevance. In contemporary economic research, the study of the diversity of factors of national economic growth is gaining more and more significance, particularly with regard to the so-called 'spatial-territorial factors'. In contrast to the existing concepts of regional and spatial economy, the approach described in this paper is based on the hypothesis that it is possible to accelerate national economic growth. It can be done by stimulating extended economic reproduction on the subnational level, that is, on the level of relatively independent and self-contained spatial and administrative units such as regions of the Russian Federation, municipalities, agglomerations, etc. Research objective. The study aims to propose a decomposition of the economic growth rates in Russia by territorial units and to describe the spatial-territorial factors of national economic growth. Data and methods. To characterize the spatial-territorial factors, we used indices of the physical volume of gross regional product (GRP) and gross value added (GVA) in types of economic activities in Russian regions in percentage to the previous year for the period of 2013-2018. The types of economic activities were specified according to the Russian Classifier of Economic Activities of 2007 (OKVED) (Statistical Classification of Economic Activities in the European Community - NACE Rev. 1.1 (2013-2016)) and OKVED-2 (NACE Rev.2 (2017-2018)). Results. We estimated the contributions of Russian regions to national economic growth by analyzing the data on the key types of economic activities in a 6-year period (2013-2018). We also identified the regions which accounted for the largest losses in economic growth, on the one hand, and those which, on the other hand, acted as drivers of the country's economic development. Conclusion. There is a small number of regions lagging in terms of GRP and their influence on the national rates of economic growth is also insignificant. The general rates of GRP decline in a region are determined, first and foremost, by the sluggish growth in those types of economic activities that have the largest share in GRP. The number and share of the regions which demonstrate extended economic reproduction, that is, deliver at least $2 \%$ growth a year, are also quite small. These regions make up slightly more than $19 \%$ of the country's GRP. The largest group of regions comprises those regions that do not go beyond the simple reproduction (their growth rates are less than $2 \%$ a year), while their share in the country's GRP exceeds $74 \%$. The so-called 'heavyweights' - regions accounting for the largest share in the country's total GRP - have the strongest effect on the national rates of economic growth, hindering it. It is the economic structure of these regions that has the biggest influence on the country's performance in such types of economic activities as wholesale and retail trade and maintenance and repair of motor vehicles. Sadly, it is in these sectors that the 'heavyweights' demonstrate the largest losses in GVA. As a result, these sectors suffer the most, which is bound to be reflected in the country's overall economic growth.
\end{abstract}

\section{KEY WORDS}

economic growth, spatialterritorial factors, regions, economic reproduction, gross regional product, types of economic activities

\section{ACKNOWLEDGEMENTS}

The research was carried out as part of the state assignment to Ufa Federal Research Centre of the Russian Academy of Sciences by the Ministry of Science and Higher Education of the Russian Federation.

\section{FOR CITATION}

Akhunov, R.R., \& Yangirov, A.V (2021) Spatial-territorial factors of economic growth in the Russian Federation. R-economy, 7(1), 42-51. doi: 10.15826/ recon.2021.7.1.004. 


\title{
Пространственно-территориальные факторы экономического роста Российской Федерации
}

\author{
P.P. Ахунов, А.В. Янгиров $\square$ \\ Уфимский федеральный исследовательский иентр Российской академии наук, Уфа, Россия; \\ jangirovav@list.ru
}

\section{АННОТАЦИЯ}

Актуальность. На современном этапе все более актуально исследование расширенной классификации факторов экономического роста национальной экономики, дополненной так называемыми «пространственно-территориальными факторами». В отличие от существующих концепций региональной и пространственной экономики, подход, описанный в этой статье, основан на гипотезе о возможности ускорения национального экономического роста. Это может быть сделано путем стимулирования расширенного экономического воспроизводства на субнациональном уровне, то есть на уровне относительно независимых и автономных пространственно-административных единиц, таких как регионы Российской Федерации, муниципалитеты, агломерации и т. д. Цель исследования - предложить декомпозицию темпов национального экономического роста в разрезе территориальных образований, оценка пространственно-территориальных факторов национального экономического роста. Данные и методы. Для характеристики пространственно-территориальных факторов использовались показатели физического объема валового регионального продукта (ВРП) и валовой добавленной стоимости (ВДС) по видам экономической деятельности в регионах России в процентах к предыдущему году за период. 2013-2018 гг. Виды экономической деятельности определены в соответствии с Российским классификатором экономической деятельности 2007 г. (ОКВЭД) (Статистическая классификация видов экономической деятельности в Европейском сообществе - NACE Rev.1.1 (2013-2016)) и ОКВЭД-2 (NACE Rev.2). (2017-2018)). Результаты. Мы оценили вклад регионов России в рост национальной экономики, проанализировав данные по ключевым видам экономической деятельности за 6-летний период (2013-2018 гг.). Мы также выявили регионы с учетом их значимости, с одной стороны, обуславливающие потери в национальном экономическом росте, с другой стороны, выступающие его драйвером. Выводы. Количество стагнирующих по показателю ВРП регионов невелико и влияние их на национальные темпы экономического роста является невысоким. Выявлено, что общие темпы снижения ВРП региона определяются, в первую очередь, стагнирующими тенденциями видов экономической деятельности, имеющих наибольший удельный вес в ВРП. Относительно невелики количество и масштабы регионов, показывающих расширенное воспроизводство, за критерий которого было взято достижение не менее двух процентов в среднем за год. Суммарный удельный вес подобных регионов в ВРП Российской Федерации составляет чуть более $19 \%$. Самая крупная группа - регионы, обеспечивающие лишь простое воспроизводство (темпы роста менее двух процентов в год), их удельный вес превышает $74 \%$ в ВРП Российской Федерации. Наибольший тормозящий национальные темпы экономического роста эффект оказывают так называемые регионы-«тяжеловесы», удельный вес которых наибольший в суммарном российском ВРП. В частности, ввиду сложившейся структуры экономики регионов-«тяжеловесов», в наибольшей степени они влияют на вид экономической деятельности «торговля оптовая и розничная; ремонт автотранспортных средств и мотоциклов», но именно по этому виду эти регионы демонстрируют наибольшие потери валовой добавленной стоимости. В результате этот сектор несет масштабные потери и ощутимо негативно влияет на темпы экономического роста для российской экономики в целом.

\section{КЛЮЧЕВЫЕ СЛОВА}

экономический рост, пространственнотерриториальные факторы, регионы-субъекты, воспроизводство, валовой региональный продукт, виды экономической деятельности

\section{БЛАГОДАРНОСТИ}

Работа выполнена в рамках государственного задания Уфимского федерального исследовательского центра Российской академии наук Министерства науки и высшего образования Российской Федерации.

\section{ДЛЯ ЦИТИРОВАНИЯ}

Akhunov, R.R., \& Yangirov, A.V. (2021) Spatial-territorial factors of economic growth in the Russian Federation. R-economy, 7(1), 42-51. doi: 10.15826/ recon.2021.7.1.004. 


\section{Introduction}

In Russia, regions are crucial to national economic growth, which makes the study of the country's spatial development a pertinent task. Not only do regional economic disparities bring about structural clashes but they also cause real losses in the country's gross domestic product. It is, therefore, necessary to compare the proportions of the key indicators of regions' socio-economic development in order to identify the reasons behind such disparities.

In this study we propose a decomposition of the rates of economic growth in Russia by regions by taking into account their industrial specialization and analyzing the extent to which these regions manage to realize their development potential.

Our research objectives are as follows:

1) describe the negative influence that lagging regions have on the national growth rates;

2) estimate the contribution of the regions characterized by extended economic reproduction to the country's overall economic growth;

3) analyze the development of regions that provide only simple economic reproduction.

This study centres around the spatial-territorial factors of national economic growth, including the factors of intra- and inter-territorial relationships. For the sake of brevity, this article discusses only the intra-territorial factors, in particular, the development of the key economic sectors in Russian regions.

This article summarizes the findings of the research project 'Social and Infrastructural Modernization and Restructuring of Regional Economy with the Prevailing Petro-Chemical Sector in the Context of Global Challenges of Industrial Development (the Case of the Republic of Bashkortostan)'. This project made a special emphasis on the development of the mining and manufacturing sectors in Russian regions.

\section{Literature review}

The adverse effects of external factors such as the falling oil prices, sanctions and pandemic restrictions on the Russian economy lead scholars to search for ways to realize the country's internal potential. In our view, such research should, among other things, provide a more in-depth understanding of the issues associated with regional disparities.

We share the view of Mikheeva (2016), who pointed out that 'together with the formation of a new model of national economic growth, there should evolve a certain kind of its spatial projection, which can change the modern spatial structure of economy and resolve some of the problems and disparities of spatial development.... Minakir \& Demyanenko (2010) argue that although '...the obvious failures in the search for mechanisms of economic modernization lead us to pay more attention to the potential of the territorial organization of national economy', 'hopes that the accent in the economic modernization would be shifted towards the territorial organization and management were shattered when the economic theory turned out to be totally unprepared for integrating the spatial aspect of economic development into the conventional models of general economic equilibrium and dynamics.'

On the other hand, there is a vast body of research dealing with the problems of spatial development of national economy. The seminal works in the field of spatial economics were written by Aydalot (1980), Bunge (1962), Weber (1909), Hettner (1927), Christaller (1968), Lösch (1940), Ritter (1841), Tinbergen (1962), Thünen (1826), Ullman (1957), Hagerstrand (1967), Chabot (1969) and others. Most of them were geographers, which explains why they were the first to look at the economic systems from the spatial perspective, to analyze the connections between the location of production facilities and such factors as distance, transport and operating costs, pricing, and the institutional environment.

Among the Soviet and Russian scholars who justified the need to develop state-planned economy were Alexandrov (1928), Granberg (1973), Knipovich (1925), Kolosovsky (1947), Minakir (2010), Nekrasov (1973), Chelintsev (1928), Shniper (1979) and others. Their studies describe the basic principles of economic zoning, design of territorial economic systems of different levels and specializations. In fact, it was these systems that the centralized schemes of the placement of production facilities were based on. On the other hand, '...the degree of complexity of spatial organization and spatial relationships in contemporary economics has already exceeded the theoretical and experimental capabilities of regional economics...' (Minakir \& Demyanenko, 2010), while '...the currently established territorial organization of economy does not reflect the new reality of Russia's political and economic system...' (Minakir \& Demyanenko, 2010).

Therefore, in our view, it is now imperative to expand the existing classification of the factors of 
national economy (including labour, land (natural resources), capital, technologies (technological progress)) by adding spatial-territorial factors.

In contrast to the existing concepts of regional and spatial economy, the proposed approach considers national economic growth as a complex of mutually determined subnational processes in relatively independent and self-contained spatial and administrative units such as regions of the Russian Federation, municipalities, agglomerations, etc.

In our understanding of the spatial-territorial factors of national economic growth, we take as a point of departure the idea of Yusupov (1980), who argued that subnational territorial units act as subsystems of the national economy which they are a part of.

Therefore, spatial-territorial factors comprise intra-territorial factors related to reproduction, industrial, technological, and organizational characteristics of regional economy as well as inter-territorial factors, such as specialization of regional economies, the scale of reproduction made possible by the use of internal and external resources. Intra-territorial factors may include spatial-territorial factors of a higher order in relation of lower-level territories in the hierarchy. The proposed approach can be used for the decomposition of the rates of national economic growth by multi-level territorial units and thus find optimal ways for estimating and managing the spatial-territorial potential of national economic growth.

This study estimates the contribution of individual territorial units (Russian regions) in specific types of economic activities into the national economic growth within a 6-year period (2013-2018).

\section{Data and methodology}

The methodological framework of this study relies on the indices of the physical volume of gross regional product (GRP) and gross value added (GVA) in specific economic sectors of Russian regions in percentage to the previous year for the period of 2013-2018. The types of economic activities are specified according to the Russian Classifier of Economic Activities of 2007 (OKVED) (Statistical Classification of Economic Activities in the European Community - NACE Rev. 1.1) (2013-2016) and OKVED-2 (NACE Rev.2) (2017-2018).

The period between 2013 and 2018 was chosen for the following reasons. First, in April 2011, the Russian State Statistics Service (Rosstat) started to use the new base period to calculate indices of the physical volume of GDP. Before 2011, the base period had been the year of 2003, and since 2011, in order to neutralize the differences between the structural components of the report and base periods, Rosstat has been using the year of 2008 as a base period. Second, in our view, the period between 2013 and 2018 can be seen to a certain extent as a period of economic prosperity in Russia, despite the falling oil prices and expanded financial sanctions. This period generally saw positive growth rates, with the only exception of 2015, when the physical volume of the country's GDP was $98 \%$. Third, Rosstat publishes the official GRP data with a certain delay: for example, as of January 2021, we can only access the data for 2018 or earlier. Therefore, it is for the chosen period that the most accurate estimates of regional and national economic growth can be obtained.

Our study also takes into account the transfer to OKVED-2 (version OK 029-2014 (NACE Rev. 2)) that happened in 2016 with the purpose of harmonizing the national classification with the Statistical Classification of Economic Activities in the European Community (NACE Rev. 2). Although the codes and names (classes, subclasses, groups, subgroups and types of economic activities) underwent significant changes, it is possible to recalculate the data from OKVED-2 to OKVED for types of economic activities with the help of the publicly available conversion keys and proportions in gross value added.

To exclude the cases of a random upsurge in GRP (GVA) in some years, through the product of annual (chain) indices, we obtained a data panel consisting of base indices of the physical volume of GRP and GVA in the types of economic activities in Russian regions in 2013-2018.

Our study covered 80 Russian regions. It should be noted that the data for autonomous districts (Nenets, Khanty-Mansiysk, and Yamalo-Nenets) were included into the data for higher-level administrative units (Arkhangelsk and Tyumen regions). We were unable to include the Republic of Crimea and Sevastopol due to the lack of statistical data for this period. As a result, the sum of the 80 regions' shares in GRP was less than $100 \%$ since these two regions account for about $0.5 \%$ of total national GRP. 


\section{Results}

The results of our analysis are as follows.

1 . In the given 6 -year period, only 68 regions out of 80 succeeded in showing positive economic growth and 12 regions had sagging growth rates. These regions accounted for about $6 \%$ of total national GRP (see Table 1).

Table 1

Regions with declining growth rates in 2013-2018

\begin{tabular}{|c|l|c|c|}
\hline № & \multicolumn{1}{|c|}{ Region } & $\begin{array}{c}\text { Indices of the physi- } \\
\text { cal volume of GRP } \\
\text { in 2013-2018, \% }\end{array}$ & $\begin{array}{c}\text { Share in na- } \\
\text { tional GRP } \\
\text { in 2018, \% }\end{array}$ \\
\hline 1 & Primorye region & 99.8 & 0.98 \\
\hline 2 & Chuvash Republic & 99.0 & 0.35 \\
\hline 3 & Kemerovo region & 97.9 & 1.46 \\
\hline 4 & Volgograd region & 97.3 & 1.00 \\
\hline 5 & Zabaikalye region & 96.1 & 0.38 \\
\hline 6 & $\begin{array}{l}\text { Karachay-Cher- } \\
\text { kess Republic }\end{array}$ & 95.2 & 0.09 \\
\hline 7 & $\begin{array}{l}\text { Republic of Bu- } \\
\text { ratia }\end{array}$ & 94.7 & 0.27 \\
\hline 8 & $\begin{array}{l}\text { Republic of North } \\
\text { Ossetia-Alania }\end{array}$ & 93.4 & 0.15 \\
\hline 9 & Ivanovo region & 93.0 & 0.23 \\
\hline 10 & Amur region & 92.8 & 0.35 \\
\hline 11 & $\begin{array}{l}\text { Jewish Autono- } \\
\text { mous Region }\end{array}$ & 87.4 & 0.07 \\
\hline 12 & Komi Republic & 84.7 & 0.78 \\
\hline
\end{tabular}

Source: authors' own calculations based on Rosstat data

One region that stands out from the rest if we look at the table above is the Komi Republic, whose GRP dropped by over 15\% in the given period, while its share in national GRP still remains quite large - almost $0.8 \%$. Kemerovo, Volgograd and Primorye regions together account for more than $3 \%$ of the country's GRP. In our estimates, if we take into account the total share of these three regions, it becomes evident that provided they demonstrate at least $1 \%$ growth a year, this will increase the rates of economic growth in the country by $0.6 \%$ or more, which appears quite substantial on the national scale.

For a more detailed picture of these regions' performance, we should look at specific economic sectors. At this point it should be noted that there are three types of economic activity crucial to national GRP (as of 2018): the manufacturing sector (its share is 18\%); wholesale and retail trade, maintenance and repair of motor vehicles (15.8\%); and mining and mineral extraction (14.8\%). In total, their share exceeds $48 \%$. While in manufacturing and mining, the indices of the physical volume of GVA in the given period were 115.3 and $116.0 \%$ respectively, in wholesale and retail trade, maintenance and repair of motor vehicles there was no growth (99.9\%), which slowed the country's overall economic growth. Let us now consider the possible impact of the lagging regions on the three above-mentioned sectors.

It should be noted that while the economic performance of these regions can be generally described as poor, there is a significant variation in the growth they demonstrate in different sectors. For example, if we look at the Komi Republic, which had the largest general decline in GRP, we will see that in manufacturing, this region delivered growth of $105.6 \%$ (this sector accounts for $11.5 \%$ of the region's GRP). At the same time in mining, whose share in the region's GRP reaches $44.1 \%$, the index of the physical volume of GVA is below $100 \%-97.1 \%$. The overall sluggish growth of the region is exacerbated by the negative rates of growth in the physical volume of GVA in all the other types of economic activity. Overall, our analysis shows that the region's general GRP decline is largely determined by stagnation trends in the types of economic activities with the largest share in GRP.

In terms of manufacturing, it is interesting to look at Volgograd and Kemerovo regions, ranking 20th and 21st nationwide in GVA in this type of economic activities. Their total share is almost 3\%. At the same time these regions have falling volumes of GVA: in Kemerovo region, by almost $8 \%$ and in Volgograd region, by more than $13 \%$. It should be noted that manufacturing plays the principal role in the economy of Volgograd region and is followed by wholesale and retail trade and maintenance and repair of motor vehicles. The share of the latter two is half the size of the former $-13.2 \%$.

The total share of the regions with the sagging physical volume of GVA in manufacturing was almost $3.5 \%$ in the same kind of economic activity on the national level. At the same time all of the regions in this group account for more than $5 \%$ in national GVA in manufacturing.

As for wholesale and retail trade, maintenance and repair of motor vehicles, Primorye has a prominent share $(1.2 \%)$ on the national level and demonstrates an upward trend. The total share of the regions with the shrinking physical volume of GVA in this type of economic activities was 2.4\% while the share of these regions in manufacturing in the given period was $4.1 \%$. Regarding mining and mineral extraction, the Komi Republic holds 
a considerable share $-2.3 \%$ and ranks 11 th place in Russia, although in the given period this region suffered a 3\% drop in this type of economic activity. The total share of the regions with a similar downward trend in GVA in mining is 3.1\% while the total share of the whole group is $7.3 \%$.

Therefore, the group's influence on national economic growth and on specific types of economic activity cannot be described as substantial by any stretch of the imagination. Moreover, it was found that the negative influence of the regions from this group on the three types of economic activity that are deemed crucial for Russia is virtually the same (ranging from 2.4 to $3.1 \%$ ), although this influence is lower than the total share of the whole group in the country's GVA in these sectors - between 5.2 and 7.3\%. This means that in the three given types of economic activities, some of the regions showed positive dynamics. Nevertheless, their negative impact cannot be ignored, which is why to maximize the benefit from the country's spatial potential, the federal government should target the specific needs and strengths of the regions in this group and stimulate their development selectively in the given types of economic activity.

2. Among the 68 regions with positive growth rates are the regions which did not go beyond simple economic reproduction (their index is close to $100 \%)$. Therefore, it can be supposed that, to achieve extended reproduction, the significant rates of economic growth should be on average at least $2 \%$ (or $102 \%$ ) a year, that is, $12.6 \%(112.6 \%)$ in the given period, which means that there can be only 23 of such regions (Table 2). In this respect, it is worth noting that the physical volume of national GRP in 2013-2018 was $108.1 \%$, which signifies that the federal government's failure to ensure the required $2 \%$ growth a year.

As the table above illustrates, these regions account for slightly more than $19 \%$ of total GRP of the Russian Federation, with Moscow region in the top ten. As a result, their contribution to national economic growth is only about $20 \%$.

Let us now consider the contribution of this group of regions to the three types of economic activity specified above. It should be noted that even in the most prosperous regions, the dynamics of specific sectors may vary significantly. For instance, Astrakhan region, which is the leader in terms of GRP growth rates, demonstrates a decline in manufacturing, wholesale and retail trade, maintenance and repair of motor vehicles. The share of these sectors in the region's GRP varies between 3 and 7\%. The mining sector, which accounts for almost $53 \%$ of the region's GRP, experiences a dramatic growth - almost $346 \%$. In this case it may be concluded that the regional economic growth tends to be determined by the growth in those types of economic activity that account for the largest proportion in the region's GRP.

Table 2

Regions with average economic growth rates above $2 \%$ a year in 2013-2018

\begin{tabular}{|c|l|c|c|}
\hline № & \multicolumn{1}{|c|}{ Region } & $\begin{array}{c}\text { Indices of the phys- } \\
\text { ical volume of GRP } \\
\text { in 2013-2018, \% }\end{array}$ & $\begin{array}{c}\text { Share in na- } \\
\text { tional GRP } \\
\text { in 2018, \% }\end{array}$ \\
\hline 1 & Astrakhan region & 140.2 & 0.65 \\
\hline 2 & Tula region & 130.3 & 0.75 \\
\hline 3 & Kursk region & 122.4 & 0.50 \\
\hline 4 & Tambov region & 122.4 & 0.39 \\
\hline 5 & Chechen Republic & 120.0 & 0.23 \\
\hline 6 & Belgorod region & 119.9 & 1.02 \\
\hline 7 & $\begin{array}{l}\text { Republic of Mor- } \\
\text { dovia }\end{array}$ & 119.7 & 0.27 \\
\hline 8 & Rostov region & 119.0 & 1.70 \\
\hline 9 & $\begin{array}{l}\text { Republic of In- } \\
\text { gushetia }\end{array}$ & 118.4 & 0.07 \\
\hline 10 & Magadan region & 118.1 & 0.20 \\
\hline 11 & $\begin{array}{l}\text { Republic of Dages- } \\
\text { tan }\end{array}$ & 116.7 & 0.74 \\
\hline 12 & $\begin{array}{l}\text { Republic of Ady- } \\
\text { gea }\end{array}$ & 116.6 & 0.13 \\
\hline 13 & Irkutsk region & 116.4 & 1.64 \\
\hline 14 & Voronezh region & 116.1 & 1.11 \\
\hline 15 & $\begin{array}{l}\text { Chukotka Autono- } \\
\text { mous District }\end{array}$ & 115.3 & 0.09 \\
\hline 16 & $\begin{array}{l}\text { Republic of Sakha } \\
\text { (Yakutia) }\end{array}$ & 115.2 & 0.39 \\
\hline 17 & Lipetsk region & 115.0 & 0.47 \\
\hline 18 & Bryansk region & 115.0 & 0.28 \\
\hline 19 & Republic of Altai & 114.8 & 0.47 \\
\hline 20 & Penza region & 114.7 & \\
\hline 21 & Kamchatka region & 114.5 & \\
\hline 22 & Novosibirsk region & 114.4 & \\
\hline 23 & Moscow region & 113.4 & Source: authors' own calculations based on Rosstat data \\
\hline
\end{tabular}

As far as manufacturing is concerned, the leading positions are occupied by the regions that demonstrate a persistent growth in this sphere - Moscow region (5.7\%), Rostov region (almost 2\%), Tula region (1.9\%), Lipetsk region (1.7\%), Novosibirsk region (1.1\%) and Belgorod region $(1.1 \%)$. It should be noted that this refers primarily to those regions that delivered a growth in GVA in some sectors at $100 \%$ or more. In other words, these are the regions that at least 
do not drag down the economic growth on the national level. The total share of these regions was about $18 \%$ while the total share of the whole group was $18.2 \%$.

The same two regions - Moscow (8.5\%) and Rostov (1.9\%) regions - have the largest shares in national GVA in wholesale and retail trade and maintenance and repair of motor vehicles. These regions are followed by Novosibirsk (1.5\%) and Voronezh (1.3\%) regions, Dagestan (1.1\%) and Belgorod region (0.9\%).

The regions in this group are those that showed growth in this type of economic activity. In total, they account for $18.4 \%$ of national GVA while the share of the whole group is $20.1 \%$.

As for mining and mineral extraction, the picture changes dramatically with the Republic of Sakha (Yakutia) accounting for $4.5 \%$ of national GVA; Irkutsk, 3.5\%; Astrakhan, 2.3\%; and Belgorod, $1.3 \%$. These are the regions at the top of the list. The regions that demonstrated growth in this indicator account for $13.4 \%$ of this group, which is very close to the share of the whole group - 13.7\%.

Therefore, a conclusion can be made that the leading regions in terms of GRP growth made a contribution that roughly corresponds to their shares in national GVA in the given types of economic activity. Due to their economic structure, these regions had the greatest impact on the total rates of growth in wholesale and retail trade and in maintenance and repair of motor vehicles and the least impact, on similar indicators in mining and mineral extraction.

3. Let us now consider those regions that delivered only simple economic reproduction, that is, their average annual rates of growth in GRP were less than $2 \%$. These regions prevail both in terms of their number and their share: there are 45 regions of this type and their total share exceeds $74 \%$.

It should also be noted that if all of these regions could on average provide the necessary $2 \%$ a year, in a 6-year period the overall growth rates of national GRP would be $112.3 \%$. The latter figure is quite close to the desired one, which means that there could be a $4 \%$ increase in the actual economic growth.

Our analysis of the data on the three sectors in the given regions has shown that the regions with the largest share in total national GRP occupy a special place in the general picture. Therefore, they need to be considered separately. As far as mining is concerned, there will be added one more region - Sakhalin with the share of $6.7 \%$ in national GRP in this sector and the rates of growth in the same indicator $121 \%$.

In general, it should be noted that these regions' potential to show at least minimum rates of growth was realized to the fullest in the mining sector: while their total share in GVA was $79 \%$, the economic growth in the same sector was shown by the regions accounting for $73.6 \%$. that is, the gap was slightly more than 5 percentage points. Their performance in manufacturing was slightly less impressive: the corresponding figures in this sector were $76.6 \%$ and $60.7 \%$ respectively, that is, the gap reached almost 16 percentage points. Finally, the positive growth rates in GVA in wholesale and retail trade and in maintenance and repair of motor vehicles was shown only by the regions whose share is $23.6 \%$, while their total share in national GVA in this type of economic activity exceeded $75 \%$. In other words, the regions whose total share in this type of economic activities on the national level is $51.7 \%$ exhibited poor performance. In the latter case, it is the largest regions that are primarily responsible for this negative dynamics, which we are going to discuss in more detail below.

Just as an aside, it should be noted that the first seven large regions (Tyumen and Sakhalin regions, Tatarstan, Krasnoyarsk region, Sakha (Yakutia), Kemerovo and Irkutsk regions) demonstrated a quite impressive growth in mining and mineral extraction, accounting for almost $74 \%$, which resulted in $116 \%$ growth on the national level. Meanwhile, their rates of growth in other sectors of national economy (primarily trade) resulted in lower rates nationwide $-108 \%$.

4. A number of interesting conclusions can be made if we look at the so-called 'heavyweights' of the Russian economy - the regions with the largest shares in total national GRP: the city of Moscow, Tyumen region, Moscow region, the city of St.Petersburg, the Republic of Tatarstan, Krasnodar region, Krasnoyarsk region, Sverdlovsk region, the Republic of Bashkortostan, and Samara region.

They account for over $56 \%$ of total national GRP, which makes their contribution to the national growth rates extremely important. At the same time only Moscow region managed to deliver the above-mentioned figure of $112.6 \%$. On average, in this group of regions, the growth rate was about $108 \%$, which corresponds to the national GRP growth rates $-108.1 \%$. If all the other regions in this group could deliver the minimal 
$112.6 \%$, taking into account their contribution to the country's economy, the overall increase in the national rates of economic growth would be, in our estimates, not less than $2.7 \%$ and economic growth in Russia could be more than $110 \%$ in the given period.

Let us now consider these regions' progress in the same three types of economic activities.

In manufacturing, this group of regions includes the first six regions with the largest contribution to the country's GVA in this type of economic activities:

Moscow (18.3\%), Moscow region (5.7\%), Sverdlovsk region (4.8\%), Krasnoyarsk region $(4.7 \%)$, St.Petersburg (4.7\%) and the Republic of Bashkortostan (3.8\%). Interestingly, in terms of manufacturing, St.Petersburg suffered a more than $10 \%$ drop in the physical volume of GVA, which inevitably affected national economic growth. A decline in the same indicator was also observed in Tyumen and Samara regions, which rank 11th and 13th in terms of their share in national GVA in this indicator. Thus, here we are dealing with the losses not only regarding the most significant type of economic activities but also in terms of the overall national economic growth. In total, the share of the regions that contributed the most to the growth in this indicator is $42.3 \%$ of GVA in manufacturing. The total share of this group is $51.7 \%$.

As for wholesale and retail trade, maintenance and repair of motor vehicles, the leaders are the following seven large Russian regions: the city of Moscow (38.1\%), Moscow region (8.5\%), the city of St.Petersburg (5.5\%), Tyumen region (3.2\%), Krasnodar region (3.0\%), Sverdlovsk region $(2.6 \%)$, and the Republic of Tatarstan (2.1\%). Moscow, which plays an important role in national economy and which is far ahead of other regions, stands somewhat apart from the rest in this group. It also demonstrated a $7 \%$ decrease in the volume of GVA in this type of economic activities. Apparently, Moscow is to blame for the small decline in this indicator (99.9\%) on the national level, which, in its turn, hindered general economic growth. A more than 20\% drop in this indicator was suffered by Sverdlovsk region, which ranks $7^{\text {th }}$ in terms of its contribution to national GVA in this type of economic activities, which can explain the decline in the corresponding national-level indicator. The total share of the regions in this group delivering positive growth rates in this type of economic ac- tivities is $23.4 \%$ while in total, the whole group accounts for $66.9 \%$.

Let us now look at the mineral extraction and mining sector. In this type of economic activity, Tyumen region's contribution is the most prominent $(44.7 \%)$. The region's growth rates in the above-mentioned criterion were quite satisfactory $-113 \%$. Tyumen region is followed by Tatarstan (share size, 6.0\% and growth, 108.9\% respectively), Krasnoyarsk region $(4.7 \%$ and $145.8 \%)$ and Samara region (2.5\% and $111.4 \%)$. In general, the share of these regions in the country's GVA in mining is almost $59 \%$, which is very close to the overall share of the group in this indicator.

Therefore, it can be concluded that due to their economic structure, the 'heavyweights' mostly influence such types of economic activities as wholesale and retail trade and maintenance and repair of motor vehicles. In fact, it is in these sectors that these regions demonstrate the largest losses in GVA: of the total number of regions accounting for $66.9 \%$ of GVA, only the regions with the share of $23.4 \%$ could deliver growth or at least managed to retain their previous performance gains. The latter means that these regions accounted for the largest losses in the national rates of economic growth. Although these regions' contribution to the national levels of GVA in manufacturing and mining is smaller, it still remains in proportion to their respective shares in national economy.

\section{Conclusion}

Regions play a key role in the evolving model of economic growth in the Russian Federation. This role varies considerably depending on the size and economic specialization of this or that region. It is, therefore, necessary to identify and study the spatial-territorial factors of national economic growth as well as to conduct decomposition of growth rates by region.

The hypothesis we tested in this study is that it is possible, and indeed necessary, to ensure accelerated economic growth on the national level by stimulating extended economic reproduction on the subnational level, that is, within relatively independent spatial and administrative units.

In this study we focused on Russian regions to estimate their contribution to the country's economic growth in specific types of economic activity within a 6-year period (2013-2018).

Our research findings are as follows:

1 . The number of lagging regions is comparatively small and their impact on the national 
rates of economic growth remains insignificant. It should be noted, however, that these regions demonstrate a considerable variation across different sectors of economy, which means that some of the sectors may be characterized by positive growth trends. It was found that the general decline in GRP growth tends to be determined primarily by the sluggish development in those types of economic activity that account for the largest shares in this indicator. In order to use the country's spatial potential more effectively, it is essential that the federal government should target the specific needs and advantages of the regions in this group and stimulate their development selectively in the given types of economic activities.

2 . The number and share of the regions which demonstrate extended economic reproduction, that is, deliver at least $2 \%$ growth a year, is comparatively small. The total share of such regions in the country's GRP is slightly more than $19 \%$. It was shown that these regions' general contribution roughly corresponds to their share in the national indicators of GVA in the key types of economic activities.

3. The largest group comprises the regions that do not go beyond simple reproduction (their growth rates are less than $2 \%$ a year), while their share in the country's GRP exceeds $74 \%$. We found that if all of these regions could deliver a growth of at least $2 \%$ a year on average, in the 6-year period, the rates of growth of the country's total GRP would reach $112.3 \%$, that is, in the current conditions, they could ensure a $4 \%$ increase in the country's economic growth rates.

The so-called 'heavyweights' - the regions accounting for the largest share in the country's total GRP - have the strongest effect on national economic growth, hindering it. The economic structure of these regions to the greatest extent influences the country's performance in such types of economic activities as wholesale and retail trade and maintenance and repair of motor vehicles sadly, it is in these sectors that the 'heavyweight' regions demonstrate the largest losses in GVA. As a result, these sectors suffer the most, which is bound to be reflected in the country's overall economic growth. The fact that the first seven large regions (Tyumen region, Sakhalin, Tatarstan, Krasnoyark region, Sakha (Yakutia), Kemerovo and Irkutsk regions), accounting for almost 74\% of GRP, demonstrated considerable growth rates in mining, makes the situation look slightly more optimistic. To some extent, this trend compensated for the sluggish growth in other regions.

Our research findings can be of interest to policy-makers in the sphere of spatial development, especially regarding ways to minimize regional disparities in Russia.

\section{References}

Aydalot, P. (1980) Dynamique spatiale et développement inégal. Paris: Ed. ECONOMICA, 354.

Bunge, W. (1962). Theoretical geography. Lund: Royal University of Lund, Dept. of Geography; Gleerup, 289.

Chabot, G. (1969). Geographie regionale de la France. Paris, Masson et Cie, 435.

Christaller, W. (1968). Die zentralen Orte in Süddeutschland: Eine ökonomisch-geographische Untersuchung über die Gesetzmässigkeit der Verbreitung und Entwicklung der Siedlungen mit städtischen Funktionen. Darmstadt: Wissenschaftliche Buchgesellschaft, 331.

Hagerstrand, T. (1967). Innovation Diffusion as a Spatial Process. Lund: Gleerup, 485.

Hettner, A. (1927). Die Geographie ihre Geschichte, ihr Wesen und ihre Methoden. Breslau: F. Hirt, 463.

Lösch, A. (1940). Die räumliche Ordnung der Wirtschaft: eine Untersuchung über Standort, Wirtschaftsgebiete und internationalem Handel. Jena: Fischer, 455.

Ritter, C. (1841). Die Erdkunde Im Verhaltniss Zur Natur Und Zur Geschichte Des Menschen: Oder Allgemeine Vergleichende Geographie, ALS Sichere Grundlage Des Studiums Und Unterrichts in Physikalischen Und Historischen Wissenschaften. Berlin: G. Reimer, 876.

Thünen, J. (1826). Der isolirte Staat in Beziehung auf Landwirthschaft und Nationalökonomie, oder Untersuchungen über den Einfluß, den die Getreidepreise, der Reichthum des Bodens und die Abgaben auf den Ackerbau ausüben. Hamburg : bei Friedrich Perthes, 290.

Tinbergen, J. (1962). Shaping the world economy: suggestions for an international economic policy. New York: Twentieth Century Fund, 330.

Ullman, E. (1957). American commodity flow: a geographical interpretation of rail and water traffic based on principles of spatial interchange. Seattle: University of Washington Press, 215. 
Weber, A. (1909). Über den Standort der Industrie. Teil 1. Reine Theorie des Standorts. Toronto: Tübingen, J.C.B. Mohr (Paul Siebeck), 246.

Alexandrov, I.G. (1928). Industrial Zoning and its Methodology. Part I. Planovoye khozyastvo, 4, 46-65.

Gross Regional Product. (08.01.2021). Official site of the Federal State Statistics Service. [Electronic resource]. Retrieved from https://rosstat.gov.ru/accounts\#

Granberg, A.G. (1973). Optimization of the Territorial Proportions of National Economy. Moscow: Ekonomika, 248.

Knipovich, B.N. (1925). Agricultural Zoning. Moscow: Novaya derevnya, 192.

Kolosovsky, N.N. (1947). Industrial-Territorial Complex in Soviet Economic Geography. Voprosy geografii, 6, 133-168.

Minakir, P.A. (1983). Economic Development of Regions: Strategic Approach. Ed.A.G. Zeldner, N.I. Tsvetkov; Institute of Economic Studies, Far Eastern Branch of the Academy of Sciences of the USSR. Moscow: Nauka, 224.

Minakir, P.A., Demyanenko, A.N. (2010). Spatial Economics: Evolution of Approaches and Methodology. Ekonomicheskaya nauka sovremennoy Rossii, 3, 7-26.

Mikheeva, N.N. (2016). Preconditions for the Formation of a New Model of Economic Growth: Spatial Aspect. Research papers: Institute of Economic Forecasting of the Russian Academy of Sciences, $14,586-605$.

Nekrasov, N.N. (1973). Economy of the USSR as an Integral Economic Complex. Moscow: Znanie, 63.

Chelintsev, A.N. (1928). Methodology of Agricultural Micro-Zoning. Moscow: Novaya derevnya, 40.

Shniper, R.I. (1979). Regional Pre-Plan Studies: (Economic Aspect). Ed. B.P. Orlov. Novosibirsk: Nauka. Siberian Branch, 367.

Yusupov, K.N. (1980). Autonomous Republic in the System of Social Reproduction. Moscow: Nauka, 189.

\section{Information about the authors}

Rustem R. Akhunov - Doctor of Economics, Associate Professor, Chief Researcher, Head of the Laboratory of Regional Economy Problems, Ufa Federal Research Center of the Russian Academy of Sciences (71, Oktyabrya Ave., Ufa, 450054, Russia); e-mail: priemnaya.akhunov@mail.ru.

Azat V. Yangirov - Doctor of Economics, Associate Professor, Chief Researcher of the Laboratory of Contemporary Problematic Regional Economy, Ufa Federal Research Center of the Russian Academy of Sciences Sciences (71, Oktyabrya Ave., Ufa, 450054, Russia); e-mail: jangirovav@list.ru

ARTICLE INFO: received December 24, 2020; accepted March 3, 2021

\section{Информация об авторах}

Ахунов Рустем Ринатович - доктор экономических наук, доцент, главный научный сотрудник, заведующий лабораторией современных проблем региональной экономики, Уфимский федеральный исследовательский центр РАН (450054, Россия, г. Уфа, пр-т Октября, д. 71); e-mail: priemnaya.akhunov@mail.ru.

Янгиров Азат Вазирович - доктор экономических наук, доцент, главный научный сотрудник лаборатории современных проблем региональной экономики, Уфимский федеральный исследовательский центр РАН (450054, Россия, г. Уфа, пр-т Октября, д. 71); e-mail: jangirovav@list.ru.

ИНФОРМАЦИЯ О СТАТЬЕ: дата поступления 24 декабря 2020 г.; дата принятия к печати 3 марта 2021 г. 